\title{
POLA PERGERAKAN BLUE SWIMMING CRAB (Portunus pelagicus) TERHADAP CAHAYA
}

\section{THE PATTERN OF MOVEMENT OF BLUE SWIMMING CRAB (Portunus pelagicus) TO LIGHT}

\author{
Intan Roihatul Jannah Hasly ${ }^{1}$,Wazir Mawardi², Roza Yusfiandayani ${ }^{2}$ \\ ${ }^{1}$ Program Studi Teknologi Perikanan Laut, \\ ${ }^{2}$ Departemen Pemanfaatan Sumberdaya Perairan, \\ Fakultas Perikanan dan Ilmu Kelautan, Institut Pertanian Bogor \\ Korespondensi: Intanrj.hasly@ymail.com
}

\begin{abstract}
Lamp technology as a tool for fishing has long been used by Indonesian fishermen and grow not only for pelagic but also for demersal species such as crustaceans. Rajungan is one of the important crustaceans that have high economic value. Fishermen catch the crab using a trap or bottom gillnet. The two fishing devices are operated passively so that they need a tool to attract the crab. In this study tried to develop lamp technology as a lure of crabs. Responses are an important part of knowing crab behavior. The research was conducted in an experimental laboratory, where environmental conditions were controlled by researchers. The study aimed to analyze the patterns and response rates of crab to different light, including purple, blue, green, orange, red and white. A comparative descriptive analysis is used to determine the differences in patterns formed. The test results showed that the pattern of the crab against different light divided into directly and indirectly. Rajungan was approaching to light direclty for $0,072 \mathrm{~m} / \mathrm{s}$ and indirectly for $0,036 \mathrm{~m} / \mathrm{s}$. The fastest crab rate in blue at $0.081 \mathrm{~m} / \mathrm{s}$ dan the latest crabs arrive the red light at $0,026 \mathrm{~m} / \mathrm{s}$. The rate and pattern of the crab closer to white and blue light are shorter and has a short trajectory that can be suggested as a tool to used bottom gillnet, while the red and orange colors that have a slower rate of crab can be used as a trap.
\end{abstract}

Keywords: artificial light, crustaceans, movement, responses

\begin{abstract}
ABSTRAK
Teknologi lampu sebagai alat bantu dalam penangkapan ikan telah lama digunakan oleh nelayan Indonesia. Penggunaan lampu terus berkembang bukan hanya untuk spesies pelagis, juga untuk spesies demersal seperti krustasea. Rajungan merupakan salah satu krustasea yang memiliki nilai ekonomis penting. Nelayan menangkap rajungan dengan menggunakan bubu (trap) atau jaring rajungan (bottom gillnet). Kedua alat tangkap tersebut dioperasikan secara pasif sehingga membutuhkan alat bantu untuk memikat rajungan. Pada penelitian ini mencoba untuk mengembangkan teknologi lampu sebagai pemikat rajungan. Respons menjadi bagian penting dalam mengetahui tingkah laku rajungan. Penelitian dilakukan secara experimental laboratory, dimana kondisi lingkungan dikontrol oleh peneliti. Tujuan dari penelitian adalah menganalisis pola dan laju respons rajungan terhadap cahaya yang berbeda, diantaranya warna ungu, biru, hijau, oranye, merah, dan putih. Pola pergerakan respons rajungan diketahui dari zona yang telah terbagi menjadi tiga bagian, yaitu zona starting, searching, dan finding. Analisis deskrif komparatif digunakan untuk mengetahui perbedaan pola yang terbentuk. Hasil uji menunjukkan pola rajungan terhadap cahaya berbeda terbagi menjadi dua, yaitu menuju cahaya secara langsung dan tidak langsung. Rajungan menuju cahaya secara langsung selama $0,072 \mathrm{~m} / \mathrm{s}$ dan tidak langsung selama $0,036 \mathrm{~m} / \mathrm{s}$. Laju rajungan tercepat mendekat pada warna biru sebesar $0,081 \mathrm{~m} / \mathrm{s}$ dan terlama pada warna merah $0,026 \mathrm{~m} / \mathrm{s}$. Laju dan pola rajungan mendekat cahaya putih dan biru lebih singkat dan memiliki lintasan pendek dapat disarankan sebagai alat bantu dengan menggunakan bottom gillnet, sedangkan warna merah dan oranye yang memiliki laju rajungan lebih lambat dapat digunakan sebagai alat bantu bubu (trap).
\end{abstract}

Kata kunci: krustasea, lampu, pergerakan, respons 


\section{PENDAHULUAN}

\section{Latar belakang}

Teknologi lampu merupakan salah satu alat bantu pemikat yang digunakan untuk menangkap ikan. Alat penangkapan ikan yang memanfaatkan cahaya sebagai alat untuk mengumpulkan ikan diantaranya purse seine dan lift net (bagan), sedangkan untuk jenis alat tangkap lainnya belum popular di Indonesia (Baskoro dan Taurusman 2011). Penelitian penggunaan lampu LED pada penangkapan ikan pernah dilakukan oleh Puspito et al. (2015) dan Susanto et al. (2017) pada bagan tancap, hasilnya adalah LED memiliki efisiensi dan efektivitas tinggi. Selanjutnya Hamidi et al. (2017) pada bagan perahu, kemudian Nguyen dan Tran (2015) pada purse seine dan Nguyen et al. (2017) pada traps. Sebagian besar hasil penelitian menyatakan bahwa penggunaan LED memiliki efektifitas dan efisiensi yang baik.

Perkembangan teknologi lampu sebagai pemikat juga turut dimanfaatkan dalam penangkapan di dasar perairan, misalnya perangkap (traps). Nguyen dan Wringer (2018) mengungkapkan bahwa penggunaan LED tidak hanya untuk menarik spesies pelagis, tetapi juga ikan demersal (misalnya, cod) ataupun menarik krustasea (misalnya snow crabs). Hasil penelitian Bryhn et al. (2014), pada LED hijau (523 $\mathrm{nm})$ yang diletakkan pada alat tangkap traps dengan umpan dapat meningkatkan CPUE dan WPUE ikan cod sebesar 74\% dan $80 \%$. Penelitian lain oleh Nguyen et al. (2017) menambahkan LED dengan umpan pada alat tangkap traps dapat meningkatkan hasil tangkapan sebesar 77\% sedangkan bubu dengan LED (tanpa umpan) hasil tangkapannya sebanding dengan bubu berumpan.

Penelitian ini mencoba untuk mengembangkan teknologi alat bantu pada penangkapan rajungan. Nelayan biasanya menggunakan alat tangkap seperti bubu (trap) atau jaring rajungan (bottom gillnet). Alat tangkap yang digunakan bersifat pasif sehingga membutuhkan alat bantu (pemikat) untuk menarik perhatian rajungan agar tertangkap. Pada bubu, nelayan biasa menggunakan umpan sebagai pemikat, sedangkan pada jaring, nelayan belum menambahkan teknologi sehingga masih dioperasikan secara tradisional. Permalasahan yang terjadi pada umpan adalah dengan semakin lama perendaman di dalam perairan akan membuat performa dari umpan sebagai pemikat menurun sehingga banyak ditemui umpan yang masih utuh dan dibuang di laut dan mempengaruhi dari hasil tangkapan nelayan (Tallo 2015; Perdiana et al. 2014; Putri et al. 2013).

Pengetahuan tingkah laku ikan penting sebagai ilmu dasar dalam pengembangan penangkapan ikan. Respons merupakan bagian penting dari tingkah laku sebagai akibat dari perlakuan yang diberikan. Pola dan laju respons menjadi bagian yang tidak terpisahkan dari tingkah laku untuk mengetahui kecenderungan respons rajungan terhadap cahaya. Salah satu hasil penelitian laboratorium mengenai respons mimi terhadap lampu LED pernah dilakukan oleh Supadminingsih (2018), hasilnya adalah respons langsung berupa mimi bergerak dari area start menuju lampu (straight to light) dan respons tidak langsung dimana mimi bergerak dari start menuju lampu secara bertahap dengan beberapa jeda berhenti dan menyusuri sisi dinding area lampu kemudian menetap diarea lampu (side to light). Hasil penelitian lain mengenai tingkah laku kepiting (snow crabs) pernah dilakukan oleh Nguyen et al. (2017), hasilnya adalah kepiting mendekat pada warna biru dan putih, menjauh dari warna ungu.

Rajungan merupakan filum arthropoda dari kelas krustasea dan sub kelas malacostraca (Stephenson dan Campbell 1959). Krustasea yang juga merupakan hewan akuatik turut memanfaatkan cahaya sebagai stimulus seperti hewan pelagis lainnya (Nguyen dan Winger 2018). Kemampuan krustasea dalam menerima cahaya berbeda-beda baik secara kelas maupun spesies, hal tersebut berkaitan dengan fungsi reseptor yang dimiliki pada masing-masing krustasea (Glantz dan Barnes 2002). Terdapat perbedaan dalam struktur mata antara ikan, krustasea (yaitu, udang, kepiting), dan cephalopoda (yaitu cumi-cumi dan gurita) (Nguyen dan Winger 2018). Krustasea memiliki mata majemuk yang melibatkan banyak komponen sistem visual didalamnya (Johnson et al. 2002). Mata majemuk terdiri dari unit reseptif individu yang disebut ommatidia (Doujak 1985). Sel retinular pada ommatidium membantu decapoda krustasea untuk menyerap berbagai panjang gelombang (Nguyen dan Winger 2018).

Perlakuan yang digunakan dalam penelitian ini adalah dengan berbagai warna lampu LED, diantaranya warna 
ungu, biru, hijau, oranye, merah, dan putih. Pemilihan keenam warna lampu dikarenakan penelitian mengenai respons penglihatan rajungan terhadap LED belum pernah dilakukan di Indonesia, sehingga pendekatan yang dilakukan dari sensitivitas spektral dari jenis krustasea dengan genus berbeda, dimana spektrum cahaya dari gelomban cahaya pendek sampai panjang dapat diketahui kecenderungan respons rajungan yang dilihat dari pola dan laju rajungan menuju cahaya. Tujuan dari penelitian ini adalah untuk menganalisis pola dan laju respons rajungan terhadap cahaya yang berbeda. Harapannya dari penelitian ini dapat menjadi salah satu upaya dan peluang dalam pengembangan alat bantu penangkapan rajungan di masa mendatang.

\section{METODE PENELITIAN}

\section{Waktu dan tempat}

Penelitian dilaksanakan dari bulan Desember 2018 sampai dengan Maret 2019, bertempat di Balai Administrasi Pelatihan Perikanan Lapangan (BAPPL) Serang, Banten. Rajungan didapat dari hasil tangkapan nelayan bubu Karangantu pada perairan Teluk Banten. Setelah ditangkap dalam kondisi hidup, rajungan ditransportasikan menuju tempat pengamatan di laboratorium.

Ukuran rajungan yang digunakan adalah dengan lebar karapas lebih dari 100 mm (rajungan dewasa) dan dalam kondisi tidak bertelur, sesuai dengan peraturan menteri kelautan dan perikanan tahun 2016 mengenai ukuran rajungan yang boleh ditangkap. Struktur ukuran lebar karapas rajungan menunjukkan adanya struktur umur yang berbeda seperti umur rajungan muda dan dewasa (Kembaren et al. 2012). Upaya untuk memastikan umur rajungan sama digunakan asumsi yaitu rajungan yang memiliki lebar karapas lebih dari 100 $\mathrm{mm}$ atau tergolong dalam kategori rajungan dewasa.

Perlakuan pada penelitian ini adalah enam warna lampu LED berbeda (ungu, biru, hijau, oranye, merah, dan putih), tipe super bright $5 \mathrm{~mm}, 3,2-3,4 \mathrm{~V}$, dan 0,02 A yang dinyalakan dengan sumber baterai 3 V. Pemilihan warna lampu didasarkan pada sensitivitas spektral pada hewan uji jenis krustasea maupun genus Portunus yang memiliki kesamaan dalam kelas maupun spesies dengan rajungan. Selain pendekatan sensitivitas, pemilihan warna juga didasarkan pada warna yang digunakan pada penelitian sebelumnya oleh Nguyen et al. (2017).

Bak fiber digunakan sebagai bak perlakuan dengan ukuran $2 \mathrm{~m} \times 1,5 \mathrm{~m} \times$ $0,5 \mathrm{~m}$ dengan ketinggian air $30 \mathrm{~cm}$, yang dibagi menjadi tiga zona yaitu starting, searching, dan finding (Gambar 1). Terdapat dua pilihan bagi rajungan yaitu memilih area cahaya atau area gelap. Sebelum pengamatan, rajungan diaklimatisasi pada kotak start selama 30 menit dan waktu uji dilakukan selama 15 menit.

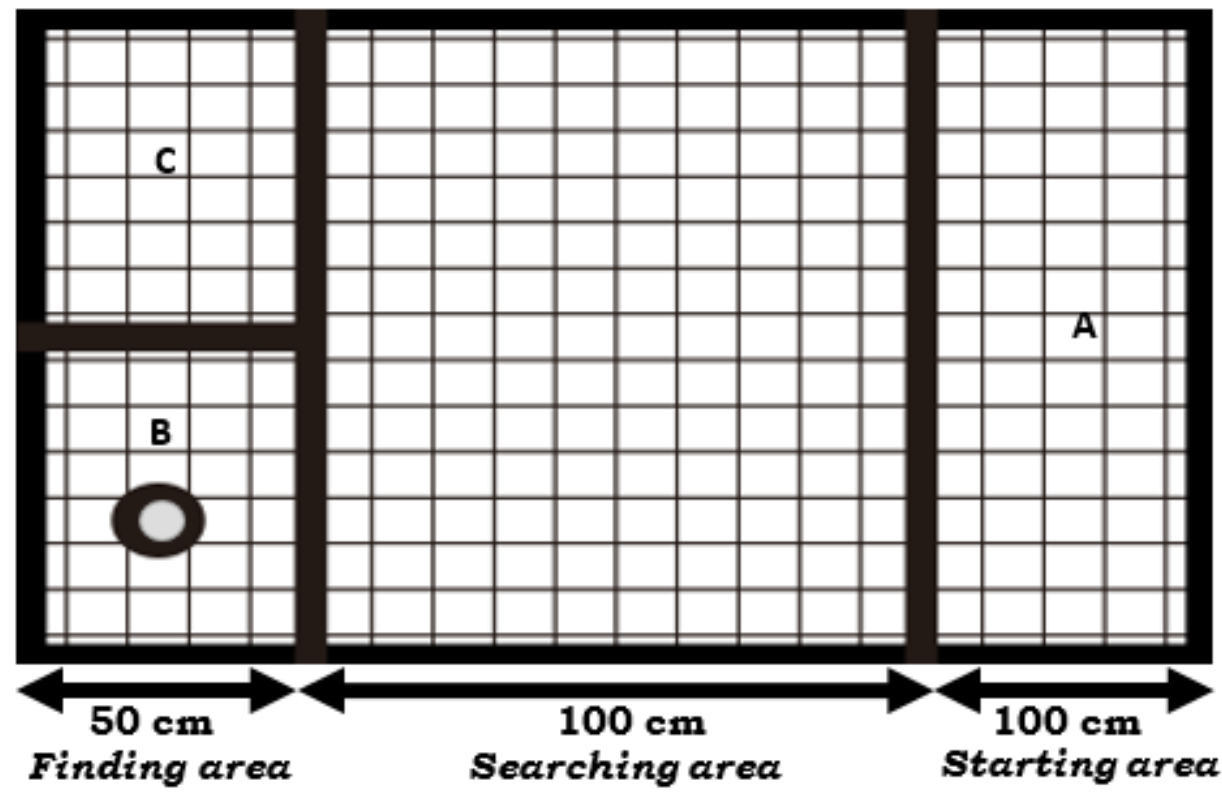

Gambar 1. Design bak perlakuan tampak atas 
Pola respons juga dapat diketahui dari kecepatan respons rajungan menuju sumber cahaya dibagi dengan jarak lintasan yang dilalui oleh rajungan. Satuan laju respons adalah dalam satuan meter per detik $(\mathrm{m} / \mathrm{s})$. Perhitungan jarak rajungan diketahui dari garis bantu pada bak perlakuan dengan ukuran $10 \times 10 \mathrm{~cm}$, kemudian dicatat total jarak yang ditempuh sampai menuju area lampu. Laju rajungan yang dihasilkan pada tiap masing-masing pola berdasar perlakuan cahaya dibuat secara proporsi dalam bentuk persen. Data laju respons didapat dari rata-rata laju yang terbentuk pada masing-masing pola.

Ulangan yang digunakan dalam penelitian laboratorium adalah sebanyak 20 kali dengan rajungan yang berbeda-beda pada masing-masing perlakuan. Penentuan jumlah ulangan tersebut mengacu dari Hanafiah (2005) menyatakan bahwa ulangan merupakan frekuensi suatu perlakuan yang diselidiki dalam suatu percobaan. jumlah ulangan dianggap telah cukup baik bila memenuhi persamaan berikut:

$$
(r-1)(n-1) \geq 15
$$

dengan :

$\mathrm{n} \quad=$ banyaknya ulangan
$\mathrm{r} \quad$ = banyaknya perlakuan

Jumlah rajungan yang digunakan pada penelitian adalah 150 individu rajungan, dimana dilakukan 20 ulangan atau 20 rajungan di uji pada masing-masing perlakuan. Setelah perlakuan, rajungan di aklimatisasi selama lima hari untuk menghindari learning behaviour. Selama perlakuan, direkam dengan CCTV (Close Circuit Television) yang kemudian hasil video dianalisis secara deskriptif komparatif terkait pola respons mendekat cahaya dari cahaya. Uji statistik berupa uji t digunakan untuk mengetahui pengaruh laju rajungan terhadap perlakuan cahaya. Uji normalitas di uji terlebih dahulu untuk mengetahui kenormalan penyebaran data.

\section{HASIL DAN PEMBAHASAN}

\section{Hasil}

\section{Pola respons rajungan menuju cahaya}

Pola respons rajungan mendekati cahaya terbagi menjadi dua, yaitu mendekati secara langsung dan tidak secara langsung. Pembagian respons rajungan dilakukan agar mempermudah dalam pengkategorian karena respons rajungan yang berbeda-beda dan bervariasi. Gambar 2 menunjukkan pola respons rajungan secara langsung terhadap cahaya, terdapat Pola A, B, dan $\mathrm{C}$ yang merupakan pola respons rajungan menghampiri cahaya lampu secara langsung baik dari sisi kanan maupun kiri lampu.

Berdasarkan Gambar 2, terdapat perbedaan pola yang terjadi yaitu posisi rajungan saat sampai pada finding area. Pola A menunjukkan posisi rajungan yang datang dari arah samping kanan lampu dan menghadap lampu lalu kemudian berhenti pada finding area. Pola B memperlihatkan rajungan yang menghampiri lampu dari sisi kiri lampu dan berdiam dengan jarak tertentu di area tersebut. Selain menghampiri lampu, rajungan terkadang menyentuh lampu dengan capitnya atau berputar mengitari lampu dan terdiam di sisi lampu pada finding area. Pola A, B, dan C dapat ditemui pada semua perlakuan warna cahaya dengan persentasi yang berbedabeda sesuai dengan respons yang diberikan oleh rajungan.

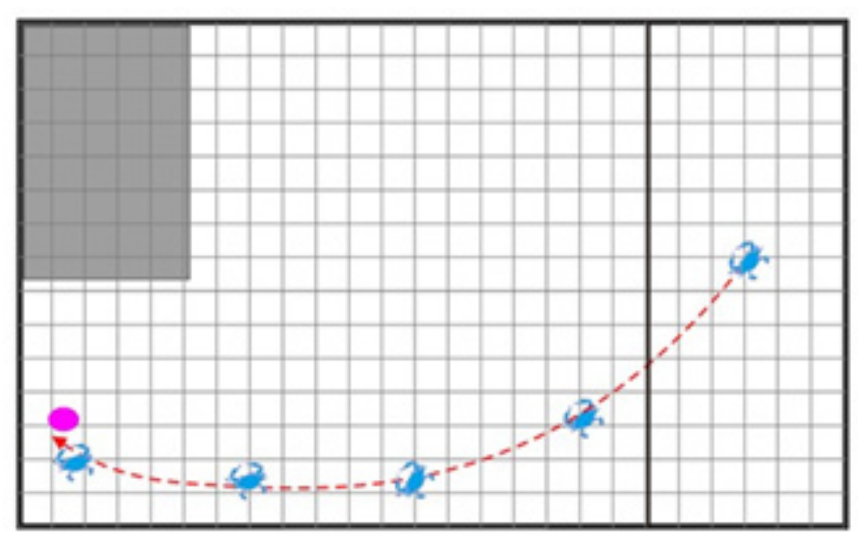

(A) 


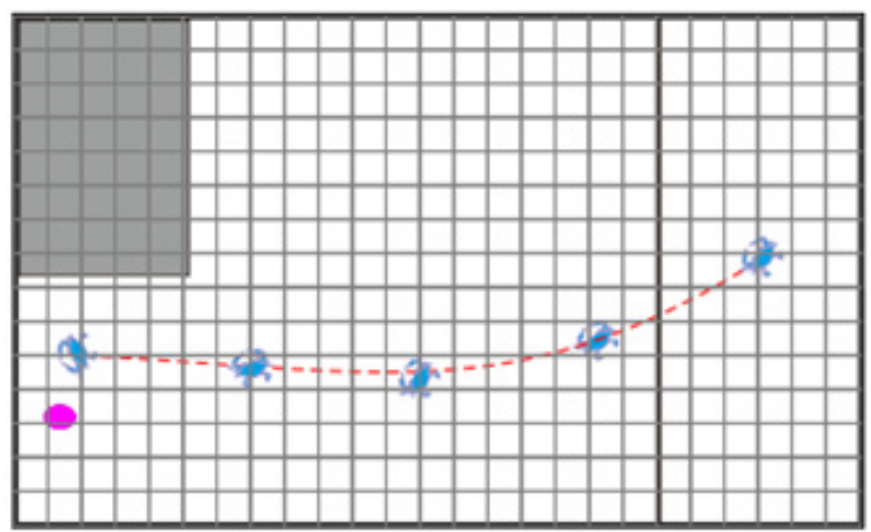

(B)

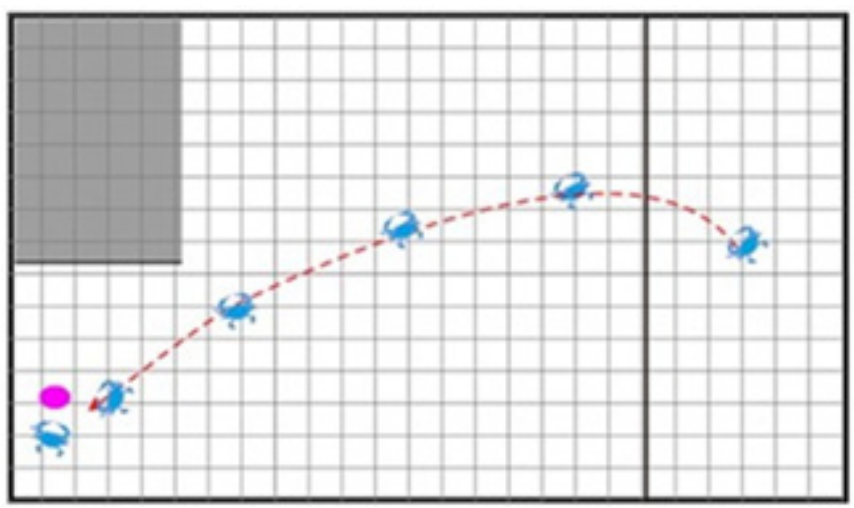

(C)

Gambar 2. Pola respons rajungan terhadap cahaya secara langsung; (A) rajungan menghampiri dari sisi kanan lampu; (B) rajungan menghampiri lampu dengan menyusuri tepian searching area sampai menuju sisi kiri lampu; (C) rajungan menghampiri lampu dari sisi tengah searching area sampai menuju sisi kanan lampu

Keterangan:

\section{$-\cdots$ : Lintasan rajungan menuju lampu \\ : Peletakan lampu LED \\ : Dark area \\ : Rajungan}

Pola rajungan terhadap cahaya secara tidak langsung terbagi menjadi 4 pola (D, E, F, dan G). Masing-masing pola tersebut menunjukkan respons rajungan yang menyusuri area searching, dark area, sebelum akhirnya sampai menuju lampu seperti ditunjukkan pada Gambar 3.

Pola pergerakan D dan E memiliki persamaan pola, dimana rajungan menyusuri area gelap terlebih dahulu sebelum akhirnya menuju ke cahaya lampu. Perbedaan pola D dan E terdapat pada penyusuran area rajungan, pada pola
D rajungan menuju dark area dahulu dan posisi pergerakan di sekat pembatas yang memiliki jarak tertentu, sedangkan pola $\mathrm{E}$ menunjukkan rajungan yang menyusuri searching area terlebih dahulu lalu kemudian menuju dark dan sampai pada akhirnya rajungan menuju lampu.

Pola pergerakan rajungan secara tidak langsung pada pola $\mathrm{F}$, menunjukkan pergerakan rajungan menuju lampu berhenti beberapa saat di searching area sampai akhirnya rajungan menuju lampu. Pola G memiliki kemiripan dengan pola $F$, namun perbedaan yang terdapat pada pola F dimana rajungan menyusuri area lebih luas dari sisi bak sebelum akhirnya menuju lampu.

Proporsi pola respons rajungan terhadap cahaya

Pola respons rajungan yang terbentuk akibat perlakuan cahaya adalah 
secara langsung (pola A, B, dan C) dan secara tidak langsung (pola D, E, F, dan G). Pengelompokkan pola respons dilakukan untuk mempermudah dalam penentuan respons, dikarenakan respons rajungan yang berbeda dan bervariasi. Selanjutnya, pola respons tersebut diproporsikan untuk mengetahui kecenderungan pola yang terbentuk dari masing-masing perlakuan terhadap respons rajungan. Proporsi pola respons selengkapnya terdapat pada Gambar 4.

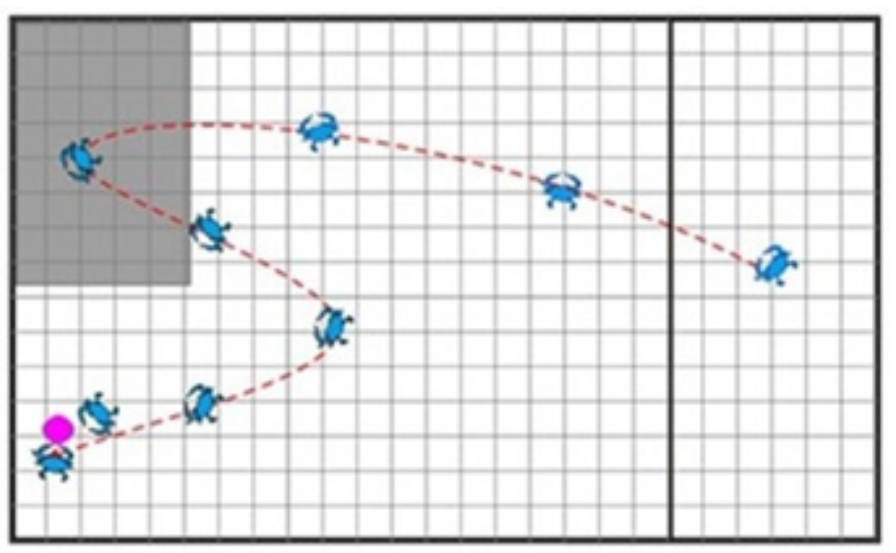

(D)

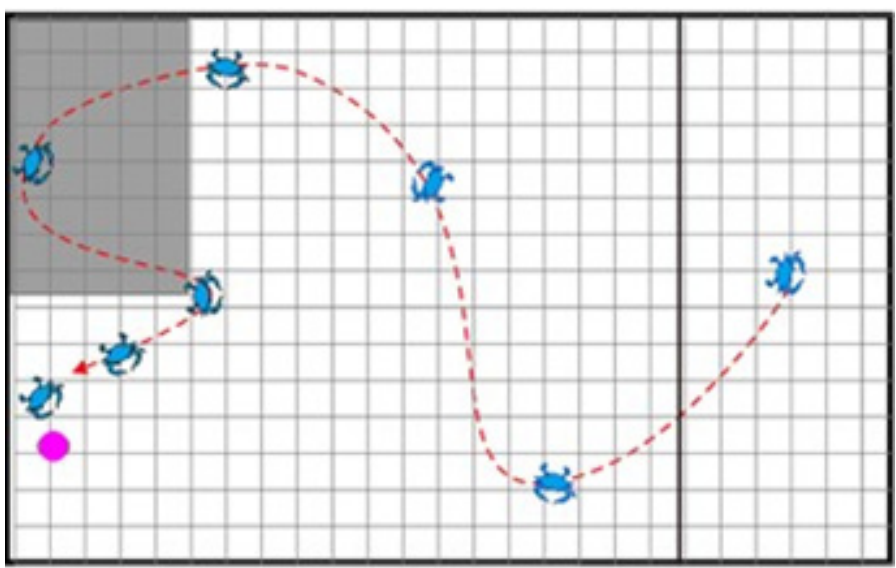

(E)

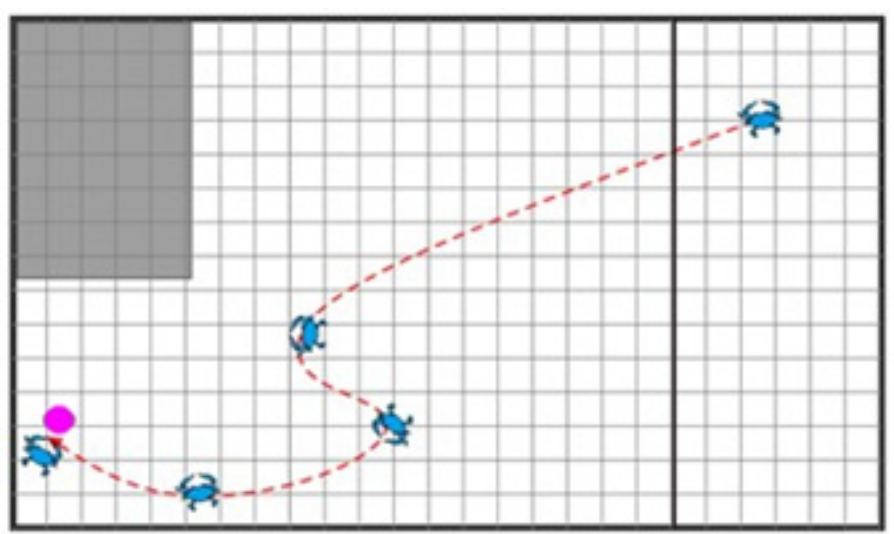

(F) 


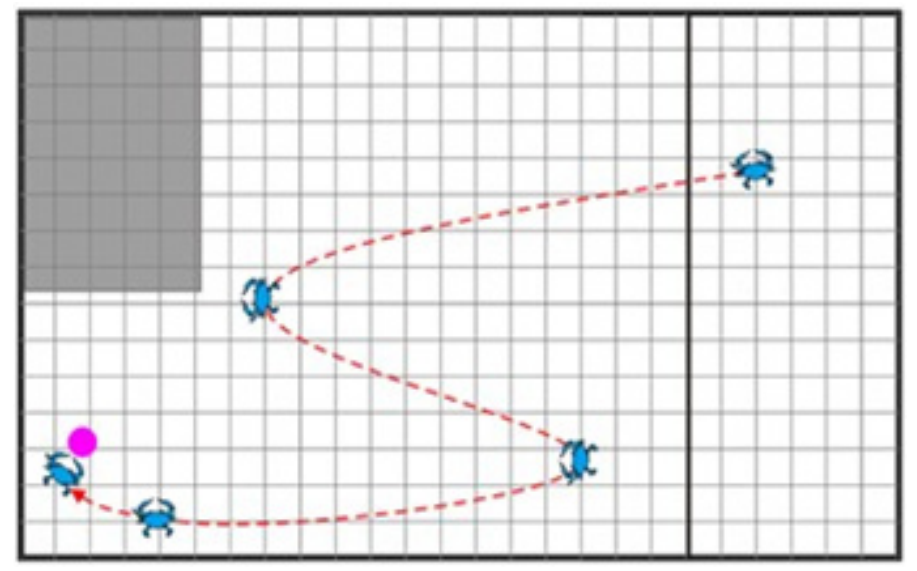

(G)

Gambar 3. Pola pergerakan rajungan menuju cahaya dengan tidak secara langsung; (D) rajungan menyusuri area gelap terlebih dahulu sebelum akhirnya menuju lampu; (E) rajungan menyusuri searching area, kemudian berhenti beberapa sampai menuju area gelap dan berputar untuk menuju area cahaya lampu; (F) rajungan berhenti pada searching area saat bergerak ke arah lampu dan bergerak kembali menuju lampu; $(G)$ rajungan bergerak di searching area sampai akhirnya menuju area lampu.

Keterangan:

\section{$\cdots$ : Lintasan rajungan menuju lampu \\ : Peletakan lampu LED \\ : Dark area \\ : Rajungan}

Gambar 4 memperlihatkan proporsi pola rajungan pada lampu ungu untuk pola A sebesar $43 \%$ dan merupakan persentase terbesar dibandingkan dengan pola lain, pola B sebesar $14 \%$, pola C, D, F masingmasing sebesar $7 \%$, dan pola $\mathrm{E}$ sebesar $21 \%$. Pola respons pada warna biru, untuk pola A sebesar $67 \%$ dan pola $F$ sebesar $33 \%$. Persentase pola respons selanjutnya pada hijau memiliki proporsi untuk pola $A$ sebesar $60 \%$, pola B dan G masing-masing sebesar $10 \%$, dan pola $\mathrm{F}$ sebesar $20 \%$. Proporsi pola respons warna oranye, pola A sebesar $50 \%$, B sebesar 13\%, D sebesar $25 \%$, dan $\mathrm{F}$ sebesar $13 \%$. Persentase pola respons selanjutnya pada warna merah, pola A sebesar $28 \%$, pola $\mathrm{F}$ dan $\mathrm{G}$ masingmasing sebesar $13 \%$. Terakhir pada lampu warna putih, persentase pola A didapat sebesar $73 \%$, pola B sebesar $9 \%$, dan pola $\mathrm{F}$ sebesar $18 \%$.
Laju respons rajungan terhadap warna cahaya berbeda

Pola respons rajungan terhadap cahaya juga dihitung berdasar jarak dan waktu sehingga di dapat data laju respons dalam satuan meter per detik. Perhitungan jarak rajungan diketahui dari garis bantu pada bak perlakuan dengan ukuran $10 \mathrm{x}$ $10 \mathrm{~cm}$, kemudian dicatat total jarak yang ditempuh sampai menuju area lampu. Waktu yang digunakan adalah waktu rajungan sampai tiba di area lampu dalam satuan detik, kemudian didapat data laju dari perhitungan jarak per waktu dan dibuat rata-rata laju pada tiap perlakuan warna cahaya.

Laju rajungan yang dihasilkan pada tiap pola berdasar perlakuan cahaya dibuat secara persentase dalam persen. Data laju respons didapat dari rata-rata laju yang terbentuk pada masing-masing pola. Selengkapnya dapat dilihat pada Gambar 5 untuk cahaya ungu, Gambar 6 untuk cahaya biru, Gambar 7 untuk cahaya hijau, Gambar 8 untuk cahaya oranye, Gambar 9 untuk cahaya merah, dan Gambar 10 untuk cahaya putih.

Gambar 5 memperlihatkan data laju respons rata-rata terhadap cahaya ungu berdasar pola respons yang terbentuk. Rata-rata laju rajungan pada pola A sebesar 
$0,094 \mathrm{~m} / \mathrm{s}$, dimana $43 \%$ rajungan memiliki pola A yang merupakan pola dominan pada cahaya ungu. Selanjutnya, rata-rata laju respons pada pola $B$ adalah $0,113 \mathrm{~m} / \mathrm{s}$, pola C sebesar $0,048 \mathrm{~m} / \mathrm{s}$, pola $\mathrm{D}$ sebesar $0,020 \mathrm{~m} / \mathrm{s}$, pola $\mathrm{E}$ sebesar $0,015 \mathrm{~m} / \mathrm{s}$, dan pola $\mathrm{F}$ sebesar $0,106 \mathrm{~m} / \mathrm{s}$. Perbedaan laju pada masing-masing pola berkaitan dengan tingkat adaptasi rajungan terhadap cahaya yang berbeda-beda. Waktu yang dibutuhkan rajungan untuk menuju cahaya secara tidak langsung lebih banyak dibandingkan dengan secara langsung menuju cahaya, hal ini karena rajungan sebelumnya menyusuri area baik searching, dark area hingga akhirnya sampai pada area cahaya. Adapun jarak rajungan terhadap lampu sebagai hasil posisi akhir rajungan dengan durasi tertentu, pada warna ungu dominan jarak yang terbentuk adalah $30 \mathrm{~cm}$ dari arah kanan maupun kiri lampu.

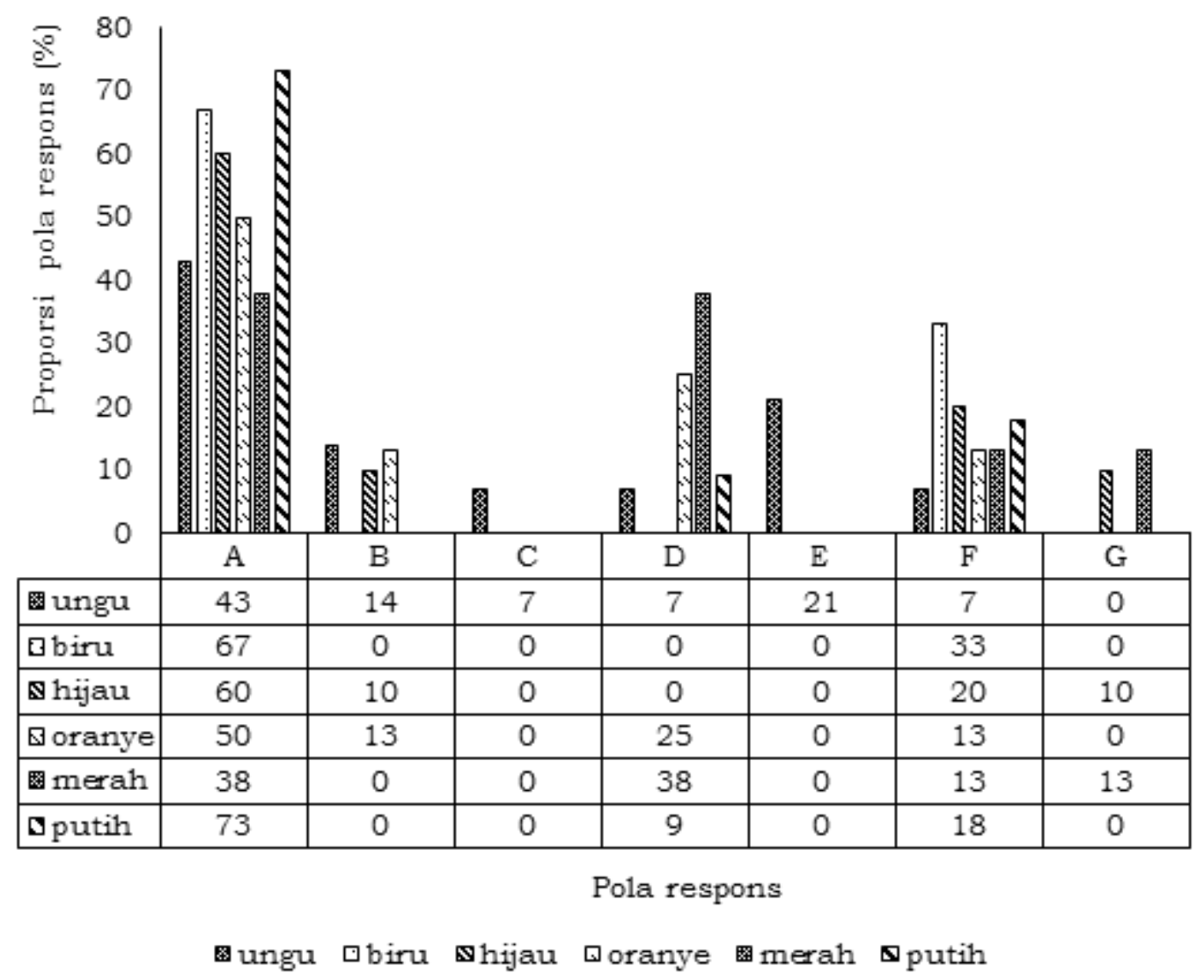

Gambar 4. Proporsi pola respons rajungan secara langsung terhadap cahaya

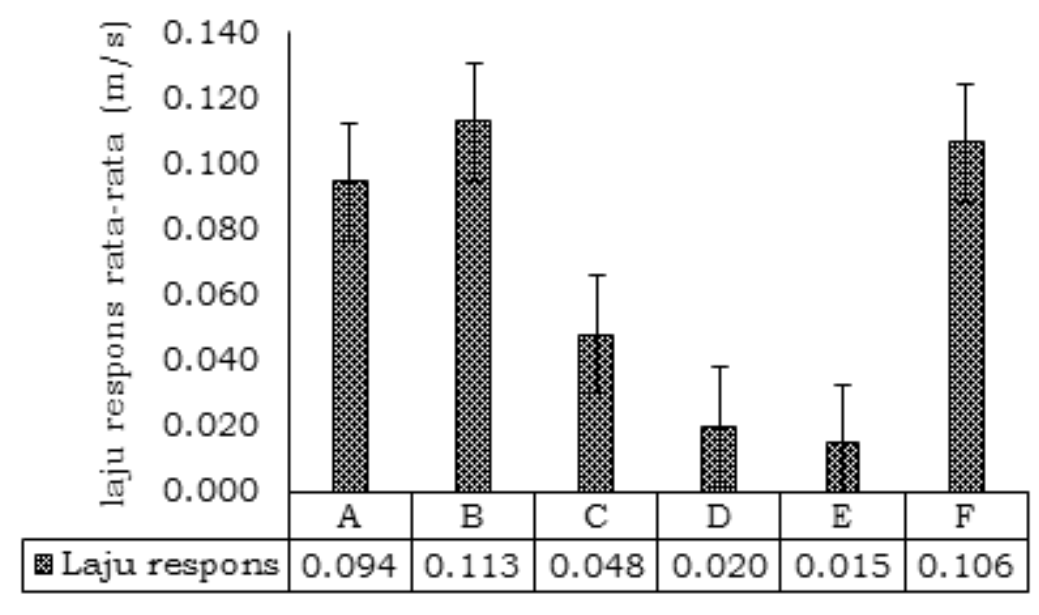

Pola respons

Gambar 5. Laju rata-rata rajungan terhadap cahaya ungu 
Gambar 6 memperlihatkan data laju rata-rata rajungan terhadap cahaya biru, dimana pola respons yang terbentuk hanya 2 pola yaitu pola A dengan laju respons ratarata sebesar $0,102 \mathrm{~m} / \mathrm{s}$, dengan persentase $67 \%$ rajungan menuju cahaya biru dengan pola $\mathrm{A}$ dan pola $\mathrm{F}$ dengan laju rata-rata $0,040 \mathrm{~m} / \mathrm{s}$. Jarak rajungan terhadap lampu untuk pola A adalah $30 \mathrm{~cm}$ dari arah kanan maupun kiri lampu.

Laju respons rata-rata pada warna hijau menunjukkan empat pola yang terbentuk seperti yang ditunjukkan oleh Gambar 7. Keempat pola tersebut diantaranya pola A dengan laju rata-rata $0,083 \mathrm{~m} / \mathrm{s}$, laju rata-rata pola B sebesar $0,125 \mathrm{~m} / \mathrm{s}$, pola $\mathrm{F}$ sebesar $0,023 \mathrm{~m} / \mathrm{s}$, dan pola $G$ sebesar $0,014 \mathrm{~m} / \mathrm{s}$. Jarak rajungan terhadap lampu untuk pola A adalah $30 \mathrm{~cm}$ dari arah kanan maupun kiri lampu.
Gambar 8 memperlihatkan laju respons rata-rata pada tiap pola yang terbentuk terhadap cahaya oranye. Ketiga pola tersebut diantaranya pola A dengan laju rata-rata $0,050 \mathrm{~m} / \mathrm{s}$, laju rata-rata pola $\mathrm{B}$ dan $\mathrm{F}$ dengan nilai masing-masing sebesar $0,008 \mathrm{~m} / \mathrm{s}$. Jarak rajungan terhadap lampu untuk pola A adalah $30 \mathrm{~cm}$ dari arah kanan lampu.

Laju respons rata-rata pada warna hijau menunjukkan empat pola yang terbentuk seperti yang ditunjukkan oleh Gambar 9. Keempat pola tersebut diantaranya pola A dengan laju rata-rata $0,046 \mathrm{~m} / \mathrm{s}$, laju rata-rata pola $\mathrm{D}$ sebesar $0,018 \mathrm{~m} / \mathrm{s}$, pola $\mathrm{F}$ sebesar $0,014 \mathrm{~m} / \mathrm{s}$, dan pola $\mathrm{G}$ sebesar $0,007 \mathrm{~m} / \mathrm{s}$. Jarak rajungan terhadap lampu untuk pola A adalah $30 \mathrm{~cm}$ dari arah kanan maupun kiri lampu.

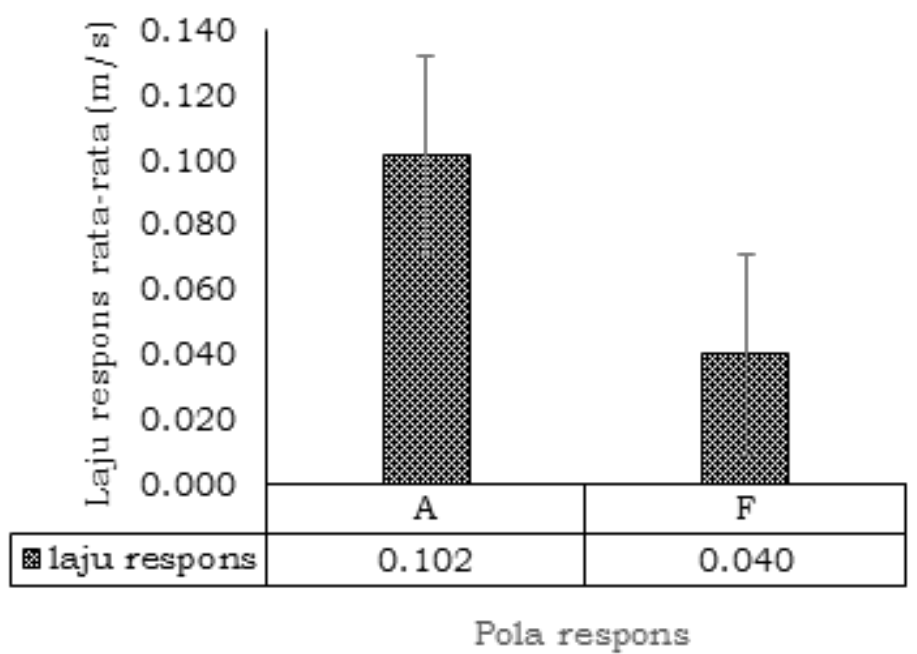

Gambar 6. Laju rata-rata rajungan terhadap cahaya biru

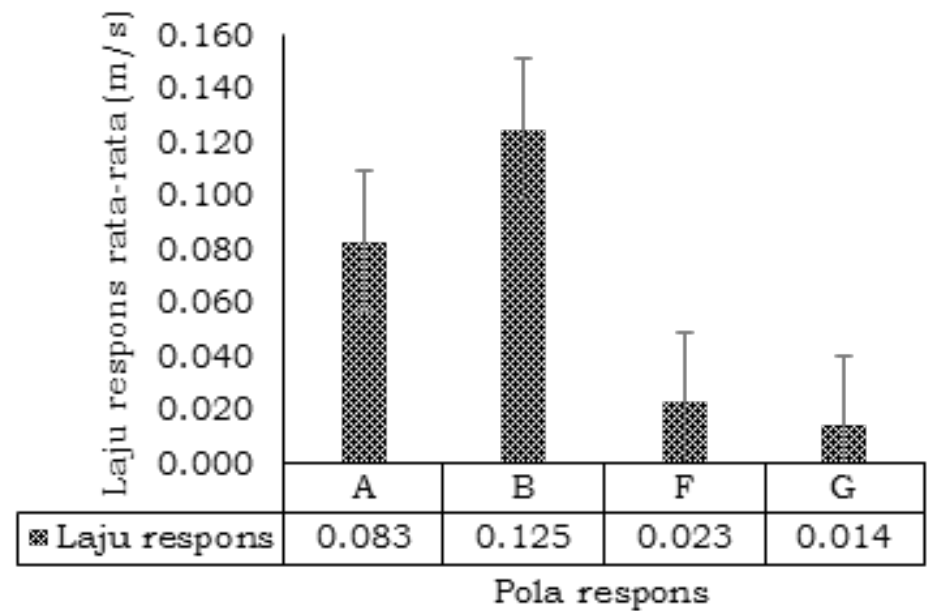

Gambar 7. Laju rata-rata rajungan terhadap cahaya hijau 


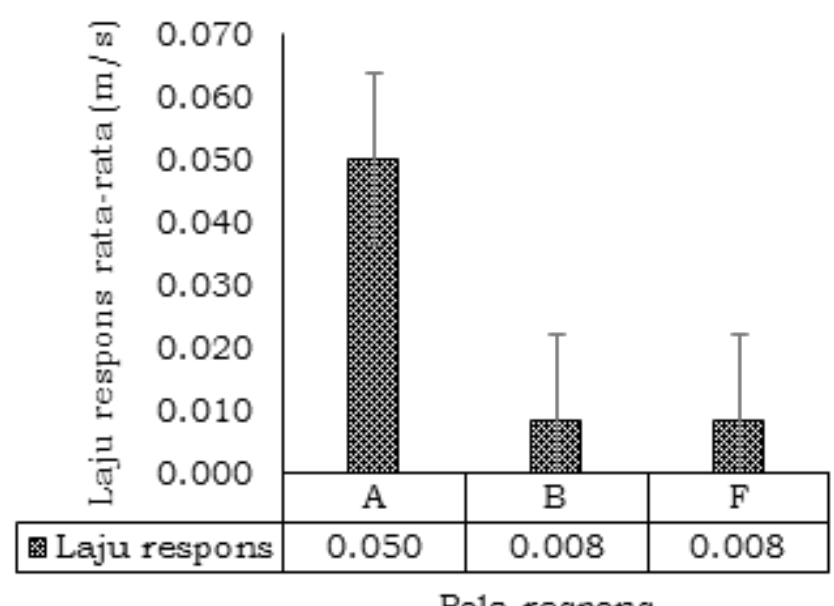

Pola respons

Gambar 8. Laju rata-rata rajungan terhadap cahaya oranye

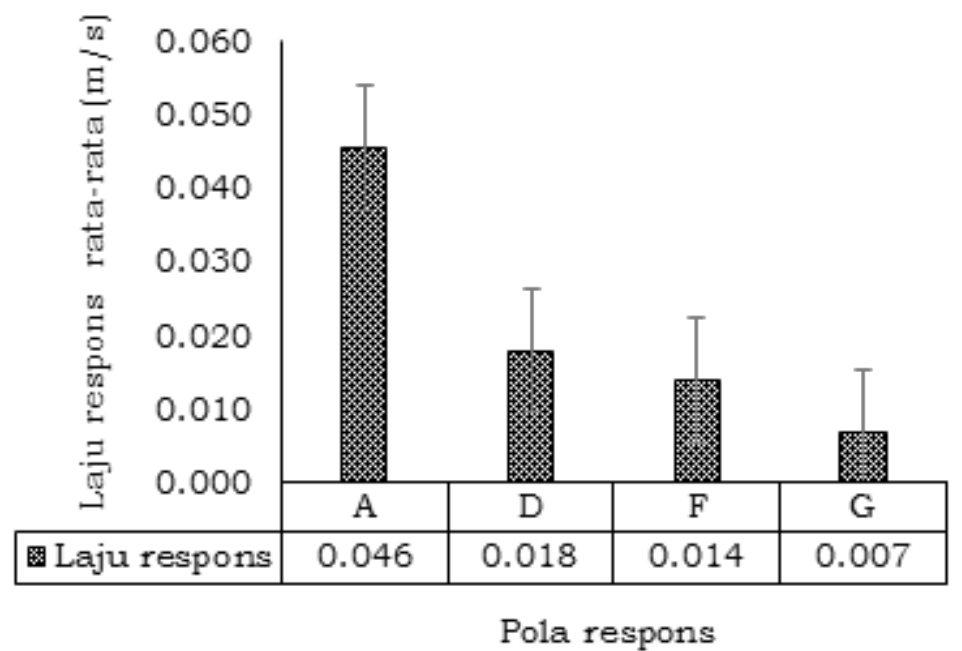

Gambar 9. Laju rata-rata rajungan terhadap cahaya merah

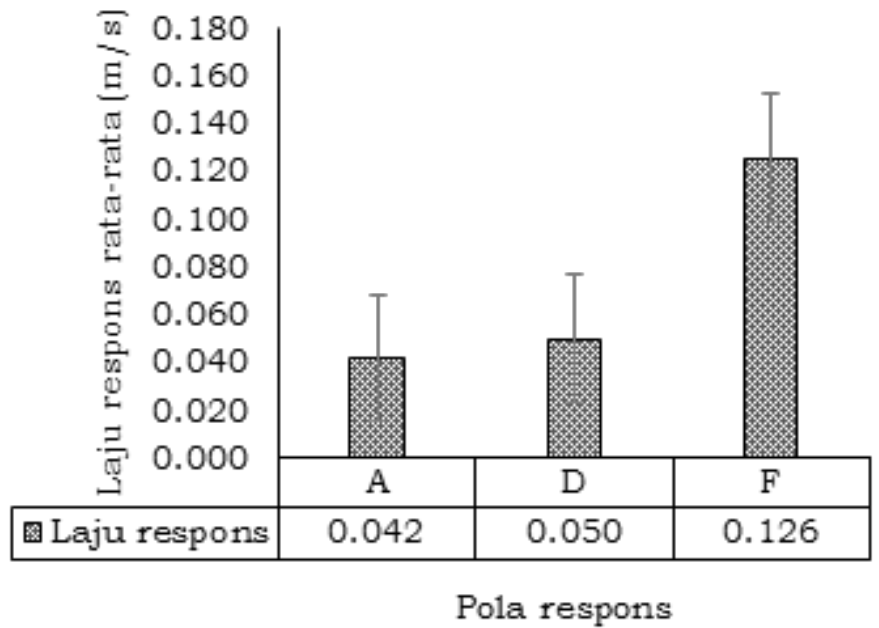

Gambar 10. Laju rata-rata rajungan terhadap cahaya putih 
Tabel 1. Uji normalitas dan uji $\mathrm{T}$ (one samples test)

\begin{tabular}{ccc}
\hline Warna Cahaya & Normalitas & Uji T \\
\hline Ungu & $0,668^{*}$ & $0,000^{*}$ \\
Biru & $0,927^{*}$ & $0,002^{*}$ \\
Hijau & $0,894^{*}$ & $0,002^{*}$ \\
Oranye & $0,542^{*}$ & $0,054^{*}$ \\
Merah & $0,991^{*}$ & $0,004^{*}$ \\
Putih & $0,142^{*}$ & $0,015^{*}$ \\
\hline
\end{tabular}

Keterangan : *normal untuk normalitas (sig. $>0,05$ )

*untuk uji $\mathrm{t}$ adalah berpengaruh nyata (sig. $<0,05$ )

Gambar 10 memperlihatkan laju respons rata-rata pada tiap pola yang terbentuk terhadap cahaya putih. Ketiga pola tersebut diantaranya pola A dengan laju rata-rata $0,042 \mathrm{~m} / \mathrm{s}$, laju rata-rata pola $\mathrm{D}$ sebesar $0,050 \mathrm{~m} / \mathrm{s}$, dan laju rata-rata pola $\mathrm{F}$ sebesar $0,126 \mathrm{~m} / \mathrm{s}$. Jarak rajungan terhadap lampu untuk pola A adalah $30 \mathrm{~cm}$ dari arah kanan maupun kiri lampu.

Pengaruh laju respons rajungan terhadap perlakuan cahaya diketahui dari uji $\mathrm{t}$, sebelumnyauji normalitas dilakukan untuk mengetahui penyebaran dan kenormalan data. Hasil uji statistik, semua data normal ditandai dengan nilai siginifikansi atau a $>0,05$, sehingga dilanjutkan dengan uji T. Tabel 1 menunjukkan hasil uji statistik (uji T) bahwa terdapat pengaruh perlakuan (warna cahaya berbeda) terhadap laju respons rajungan $(a<0,05)$.

\section{Pembahasan}

Respons rajungan terhadap warna cahaya berbeda menunjukkan respons yang berbeda-beda dan bervariasi pada tiap perlakuan cahaya. Pengelompokkan pola respons dilakukan untuk memudahkan pengidentifikasian pola yang dibentuk pada masing-masing perlakuan. Kelompok pola respons dibagi menjadi dua kategori, yaitu pola secara langsung dan tidak secara langsung rajungan menuju cahaya. Rajungan menuju area secara langsung, artinya kondisi rajungan sudah teradaptasi oleh cahaya sebagai perlakuan sehingga respons yang terbentuk adalah rajungan langsung menuju area cahaya. Pola yang terjadi secara tidak langsung, artinya bahwa rajungan membutuhkan beberapa waktu untuk beradaptasi dengan kondisi cahaya yang kemudian masuk ke finding area. Selain dari pola dan laju, juga dari posisi akhir rajungan dalam merespons cahaya berbeda.
Pada semua lampu menunjukkan bahwa sebagian besar posisi akhir jarak rajungan terhadap lampu sejauh $30 \mathrm{~cm}$. Sebelumnya, rajungan saat menuju lampu maka akan menyentuh lampu dalam beberapa saat (jarak rajungan dengan lampu uji adalah 0 $\mathrm{cm}$ ) atau mengelilingi lampu dalam beberapa detik sampai akhirnya rajungan berdiam di sisi area lampu (jarak rajungan dengan lampu $30 \mathrm{~cm}$ ).

Hasil uji pada pola respons rajungan menunjukkan bahwa pola A menjadi pola dominan yang selalu terbentuk pada tiap perlakuan lampu. Rata-rata laju berbeda sesuai dengan pola yang terbentuk, jika pola terjadi secara tidak langsung artinya bahwa rajungan banyak menghabiskan waktu di searching area sehingga jarak yang ditempuh bertambah banyak dan mempengaruhi dari laju rajungan. Kondisi lain dari pola pergerakan rajungan secara tidak langsung adalah beberapa rajungan yang lambat respons pada lampu perlakuan, seperti durasi waktu diam yang cukup lama pada sisi area searching sehingga menyebabkan laju yang lambat.

Intensitas tinggi yang dimiliki oleh lampu biru dan putih membuat rajungan cepat untuk beradaptasi menerima cahaya yang ditandai dengan laju respons relatif cepat dibandingkan dengan warna lampu lainnya. Hasil uji menunjukkan bahwa laju rajungan pada warna biru sebesar $0,081 \mathrm{~m} / \mathrm{s}$ dan pada warna putih sebesar $0,058 \mathrm{~m} / \mathrm{s}$. Pola rajungan mendekat cahaya biru dan putih dimana pola A mendominasi sebesar $67 \%$ pada biru $73 \%$ pada lampu putih. Hal ini dikarenakan intensitas yang tinggi dapat membuat mata rajungan cepat mengalami adaptasi dalam menerima cahaya. Nguyen et al. (2017) dalam hasil laboratorium menunjukkan kepiting jenis snow crab tertarik pada cahaya warna putih dan biru. Susanto (2019) dalam hasil penelitiannya 
mengungkapkan bahwa lampu LED biru dan putih merupakan salah satu lampu yang disarankan sebagai lampu pemikat (attractant lamp) untuk penangkapan ikan selar dengan intensitas minimum (threshold) sebesar 3-23 $\mu \mathrm{W} / \mathrm{cm}^{2}$. Selain itu, kecepatan rajungan menuju lampu biru dikarenakan karakteristik penyebaran cahaya pada warna biru relatif baik terabsorbsi oleh air jika dibandingkan dengan warna lainnya.

Hasil uji selanjutnya pada warna merah dan oranye yang memiliki intensitas rendah sehingga mempengaruhi respons rajungan. Laju rajungan mendekat pada lampu merah sebesar $0,026 \mathrm{~m} / \mathrm{s}$ dan $0,035 \mathrm{~m} / \mathrm{s}$ pada lampu oranye. Laju tersebut merupakan laju yang lebih lambat dibandingkan dengan lampu lain. Pola A menjadi pola dominan secara langsung mendekat pada warna merah sebesar $38 \%$ dan pada warna oranye sebesar $50 \%$. Lambat respons ini berkaitan dengan kemampuan individu rajungan dalam menerima cahaya yang lebih lama atau saat perjalanan menuju lampu, yang terjadi adalah rajungan berhenti dalam beberapa detik untuk beradaptasi dalam menerima cahaya lampu oleh retina mata rajungan. Karakteristik cahaya merah dalam perairan juga mempengaruhi respons, karena panjang gelombang cahaya yang dimiliki lampu merah cenderung panjang sehingga kurang terpenetrasi dengan baik dalam perairan.

Lampu ungu yang merupakan gelombang cahaya ultraviolet, memiliki panjang gelombang pendek dibandingkan lampu lain. Laju respons pada warna ungu sebesar $0,072 \mathrm{~m} / \mathrm{s}$. Pola dominan pada lampu ungu adalah pola A sebesar 43\%. Knight dan Legget (1985) dalam hasil penelitiannya mengungkapkan bahwa kepiting jenis Paragrapsus gaimardii sensitif salah satunya pada warna ultraviolet. Selanjutnya pada Lampu LED warna hijau dimana rajungan menghampiri lampu relatif cepat dengan laju sebesar $0,068 \mathrm{~m} / \mathrm{s}$. Pola A merupakan pola dominan rajungan dalam menghampiri lampu sebesar $60 \%$. Susanto (2019) menyatakan dalam hasil penelitianya bahwa lampu LED warna hijau memiliki efektivitas lebih baik dalam memikat, mengumpulkan, dan mengkonsentrasikan ikan dibandingkan dengan jenis lampu lainnya dengan intensitas optimum yang disarankan 4-20 $\mu \mathrm{W} / \mathrm{cm}^{2}$.

Dugaan yang menyebabkan kondisi rajungan lambat respons adalah intensitas dari lampu yang membuat rajungan membutuhkan waktu lebih untuk beradaptasi pada lampu tersebut. Warna dan intensitas memainkan peran penting dalam menghasilkan stimulus (Nguyen dan Winger 2018). Hasil uji menunjukkan bahwa pola A merupakan pola dominan yang selalu terbentuk pada tiap perlakuan lampu. Ratarata laju berbeda sesuai dengan pola yang terbentuk, jika pola terjadi secara tidak langsung artinya bahwa rajungan banyak menghabiskan waktu di searching area sehingga jarak yang ditempuh bertambah banyak dan mempengaruhi dari laju rajungan. Kondisi lain dari pola pergerakan rajungan secara tidak langsung adalah beberapa rajungan yang lambat respons pada lampu perlakuan, seperti durasi waktu diam yang cukup lama pada sisi area searching sehingga menyebabkan laju yang lambat. Posisi akhir saat rajungan di area lampu, seperti rajungan diam tepat di depan lampu, diam pada jarak $30 \mathrm{~cm}$ baik dari sisi kanan maupun kiri lampu. Selain menunjukkan bahwa rajungan menyentuh lampu maupun rajungan diam di sisi baik di sisi kanan, kiri maupun belakang lampu. Hal ini berarti bahwa lampu dapat menjadi stimulus yang dapat direspons oleh rajungan.

Respons yang merupakan bagian tidak terpisahkan dari tingkah laku, dapat digunakan sebagai dasar dalam pengembangan penangkapan. Pola rajungan dalam mendekat cahaya putih, biru, ungu, dan hijau yang secara langsung dengan laju yang lebih cepat dapat menjadi saran sebagai alat bantu penangkapan rajungan dengan menggunakan alat tangkap bottom gillnet, sehingga dapat membuat rajungan cepat untuk terjerat pada jaring. Rajungan yang memiliki pola menuju cahaya secara langsung dapat menjadi saran sebagai pengembangan alat bantu pada alat tangkap bottom gillnet, karena pengoperasian alat tangkap tersebut dengan cara menghadang pergerakan rajungan sehingga rajungan menjadi terjerat. Pola secara langsung dapat membuat peluang rajungan untuk tertangkap menjadi lebih besar karena tidak membutuhkan waktu yang lama untuk menuju pada alat tangkap bottom gillnet.

Lampu LED warna merah dan oranye memiliki pola dominan secara langsung, namun laju rajungan yang lebih lambat dapat disarankan sebagai alat bantu pada bubu (trap). Pola dominan secara tidak langsung juga dapat diterapkan untuk bubu karena rajungan dapat membutuhkan waktu yang lama untuk sampai pada bubu 
yang ditandai dengan pola pergerakan yang tidak pendek (jauh), misalnya untuk mencari pintu masuk bubu sehingga peluang untuk rajungan tertangkap menjadi besar. Prinsip pengoperasian dari bubu yang memiliki waktu perendaman cukup lama di dalam perairan sehingga dapat memberikan peluang lebih banyak bagi rajungan untuk masuk dan terperangkap pada alang tangkap tersebut. Penambahan LED sebagai alat bantu dapat sebagai stimulus dapat digunakan sebagai pemikat untuk menangkap rajungan.

Rajungan merupakan filum arthropodadarikelas krustasea dan sub kelas malacostraca (Stephenson dan Campbell 1959). Krustasea merupakan hewan akuatik juga yang turut memanfaatkan cahaya sebagai stimulus seperti hewan pelagis lainnya (Nguyen dan Winger 2018). Rajungan memilki mata majemuk yang melibatkan banyak komponen sistem visual didalamnya (Johnson et al. 2002). Mata majemuk banyak ditemukan hampir di semua kelas krustasea kecuali copepoda dan moveable stalked eyes di malacostraca (Park dan Dave 2013). Mata majemuk tersebut terdiri dari unit reseptif individu yang disebut ommatidia (Doujak 1985). Sel retinular pada ommatidium membantu decapoda krustaseaa untuk menyerap berbagai panjang gelombang (Nguyen dan Winger 2018). Ommatidia yang ditumpuk di atas rhabdom yang memungkinkan untuk merasakan cahaya untuk masuk (Schoenemann 2013). Di bawah rhabdom terdapat screening pigment granules yang dapat mengontrol cahaya yang masuk ke dalam mata (Sanudin et al. 2015).

\section{KESIMPULAN DAN SARAN}

\section{Kesimpulan}

Pola respons rajungan menuju warna cahaya berbeda dibagi menjadi dua yaitu pola secara langsung dan pola secara tidak langsung. Rajungan mendekat menuju cahaya secara langsung selama $0,072 \mathrm{~m} / \mathrm{s}$ dan secara tidak langsung selama 0,036 $\mathrm{m} / \mathrm{s}$. Laju rajungan tercepat pada warna biru sebesar $0,081 \mathrm{~m} / \mathrm{s}$ dan terlama pada warna merah sebesar $0,026 \mathrm{~m} / \mathrm{s}$.

\section{Saran}

Perlu dilakukan uji coba lapangan terkait penggunaan warna lampu untuk alat tangkap bubu dan bottom gillnet untuk menangkap rajungan.

\section{UCAPAN TERIMAKASIH}

Ucapan terimakasih disampaikan kepada Balai Administrasi Pelatihan Perikanan Lapangan (BAPPL) Serang, Banten yang telah memberikan ijin tempat selama penelitian.

\section{DAFTAR PUSTAKA}

Baskoro M, Taurusman AA. 2011. Tingkah Laku Ikan Hubungannya dengan Ilmu dan Teknologi Perikanan Tangkap. Bandung (ID): Lubuk Agung.

Bryhn AC, Konigson SJ, Lunneryd S, Bergenius MAJ. 2014. Green Lamps as Visual Stimuli Affect the Catch Efficiency of Floating cod (Gadus morhua) Pots in the Baltic Sea. Fisheries Research. 157: 187-192.

Doujak FE. 1985. Can a Shore Crab see a Star ?. J.exp.Biol. 116: 385-393.

Glantz RM, Barnes WJP. 2002. Visual Systems: Neural Mechanisms and Visual Behavior. Crustacean Experimental Systems in Neurobiology'editor', Springer: 203225.

Hamidi, Baskoro MS, Riyanto M. 2017. Penggunaan Light Emitting Diode (LED) Celup Bawah Air dengan Warna Berbeda: Pengaruhnya terhadap Hasil Tangkapan Bagan Perahu. ALBACORE. 1(3): 285-296.

Hanafiah KA. 2005. Rancangan Percobaan Teori dan Aplikasi Ed ke 3. Jakarta (ID): PT Raja Grafindo Persada.

Johnson M, Gaten E, Shelton PMJ. 2002. Spectral Sensitivities of Five Marine Decapod Crustaceans and a Review of Spectral Sensitivity Variation in Relation to Habitat. Journal of the Marine Biological Association of the UK. 82: 835-842.

Kembaren DD, Ernawati T, Suprapto. 2012. Biologi dan Parameter Populasi Rajungan (Portunus pelagicus) di Perairan Bone dan Sekitarnya. J.Lit. Perikan.Ind. 18(4): 273-281.

Knight D, Legget LMW. 1985. Six Spectral Sensitivity Classes in Crab Paragrapsus gaimardii Visual Interneurons. Journal of Comparative 
Physiology a Sesory Nerural and Behavioral Physiolofy. 157(2): 235246.

Nguyen KQ, Tran PD. 2015. Benefits of Using LED Light for Purse Seine Fisheries: A Case Study in Ninh Thuan Province, Viet Nam. Fish People. 13(1): 30-36.

Nguyen KQ, Winger PD, Morris C, Grant SM. 2017. Artificial Lights Improve the Catchability of Snow Crab (Chionoecetes opilio) Traps. Aquaculture and Fisheries. 30: 1-10.

Nguyen KQ, Winger PD. 2018. Artificial Light in Commercial Industrialized Fishing Applications : A Reviews in Fisheries Science and Aquaculture.

Park JJ, Dave B. 2013. 'Bio-inspired responsive façades', Proceedings CESBP 2013. A. Mahdavi \& B. Martens (eds), The 2nd Central European Symposium on Building Physics, 9-11 Sept., Vienna.

Perdiana, Fitri ADP, Yulianto T. 2014. Laju Asam Amino Terlarut yang Terdistribusi ke Dalam Kolom Laut pada Umpan Ikan Kembung (Rastrelliger kanagurta) (skala laboratorium). Journal of Fisheries Resources Utilization Management and Technology. 3(3): 28-36.

Puspito G, Thenu EM, Julian D, Tallo I. 2015. Utilization of Light - Emitting Diode Lamp on Lift Net Fishery. AACCL Bioflux. 8(2): 159-167.

Putri RLC, Fitri ADP, Yulianto T. 2013. Analisis Perbedaan Jenis Umpan dan Lama Waktu Perendaman Bubu pada Alat terhadap Hasil Tangkapan Rajungan di Perairan Suradadi Tegal. Journal of Fisheries
Resources Utilization Management and Technology. 2(3): 51-60.

Sanudin N, Tuzan AD, Kawamura G, Yong Annita SK. 2015. Effect of Different Lighting Conditions on Feeding Activity and Eye Adaptation of Post Larvae Penaeus vannamei. Jurnal Teknologi (Science and Engineering). 77(33): 1-6.

Schoenemann B. 2013. The Eyes of a tiny 'Orsten' crustacean - A Compound Eye at Receptor Level?. Vision Research. 76: 89 - 93.

Stephenson W, Campbell B. 1959. The Australian Portunids (Crustacea : Portunidae) III. The Genus Portunus, Aust.J.Mar.Freshwat.Res. 10(1): 84124.

Supadminingsih FN. 2018. Tingkah Laku Mimi (Limulidae, 1819 Leach) terhadap Lampu LED Warna Hijau [Tesis]. Bogor (ID): Institut Pertanian Bogor.

Susanto A. 2019. Pengembangan Teknologi Pencahayaan untuk Perikanan Lift Net yang Hemat Energi dan Ramah Lingkungan [Disertasi]. Bogor (ID): Institut Pertanian Bogor.

Susanto A, Irnawati R, Mustahal, Syabana MA. 2017. Fishing Efficiency of LED Lamps for Fixed Lift Net Fisheries in Banten Bay Indonesia. Turkish Journal of Fisheries and Aquatic Science. 17: 283 - 291.

Tallo I. 2015. Rancang Bangun Bubu Lipat dalam Upaya Peningkatan Efektivitas dan Efisiensi Penangkapan Kepiting Bakau yang Ramah Lingkungan [Disertasi]. Bogor (ID): Institut Pertanian Bogor. 